\title{
优化管理理念 促进学校发展
}

\author{
刘志磊 \\ 长沙银河中等职业学校 \\ DOI:10.32629/jief.v2i8.2183
}

[摘 要] 随着我国社会的不断向前发展, 社会对技能型人才的需求在不断提升, 这对职业院校的教育提出了更高的要求。对此, 中职院校在 对学生进行教育和管理的过程中, 应该及时了解和更新管理理念, 在对中职院校学生的特点有一个很好地把握的前提下对教育方式进行调整 和创新, 充分调动起学生的学习积极性, 同时加强对学生实践操作能力的培养, 让学生能够很好地将所学习的理论知识和实践操作联系到一 起, 从而能够更好地满足社会对技能型人才的需要。在本文中主要针对优化管理理念促使中职院校科学发展提出了几点策略, 期望能够为同 行提供一些借鉴和参考。

[关键词] 中职院校; 管理理念; 科学发展

中图分类号: G633 文献标识码: A

\section{前言}

随着科学技术的不断发展, 尤其是信息技术的快速发展, 社会对技 能型人才提出了更高的要求, 同时技能型人才在社会中也占据着更加重 要的地位。社会的发展为他们提供了新的发展机会, 当然也带来了诸多 挑战。作为中职院校的一名教育从业者, 怎样让中职院校培养的学生能 够很好地符合社会发展的需要, 能够胜任今后所要从事的工作, 将理论 知识和社会生产实践紧密地结合在一起是教育变革的过程中一定要分析 和思考的问题。在下文中主要针对优化管理理念提出了几点建议, 以此 来提升中职院校的教育质量, 促使中职院校未来更好地发展。

\section{1 树立正确的育人理念}

在新的育人观念中包含诸多新的教育理念, 其中以人为本是教育的 核心。所谓以人为本其实就是在对学生教育的过程中把尊重学生当成前 提, 将学生的全面发展当成教育的重点, 采取诸多有效策略来激发学生 的学习潜能。以人为本的教育理念要求教师在对学生开展教学工作的过 程中对不同的学生之间存在的差别予以尊重和理解, 针对不同的学生采 取针对性的教育策略来培养, 从而让每一个学生通过接受中职教育都能 够得到成长。另外, 作为中职院校的教师, 应该加强对自身所从事职业 教育工作的认知, 意识到职业教育对学生、社会以及国家所起到的重要 作用, 在教育的过程中培养自身对职业教育工作的责任感和荣誉感, 在 教学中真正将开发学生智力, 培养学生的个性和动手操作能力放在第一 的位置, 并在实践教学中不断寻找合理的教育教学方法, 形成属于自身 的独特教育风格, 同时让学生在接受职业教育的过程中得到全面发展。

\section{2 加强实践教学}

中职教育就是将学生培养成为技术型人才, 所以需要学生通过职业 教育学习掌握足够的实践操作理论知识和具备较高的动手操作能力。因 此, 教师在对学生开展教育的过程中应该为他们提供更多的自由动手的 时间和机会, 让他们更多地从事一些相关的实践工作, 让学生在动手操 作的过程中对课堂中所学习到的理论知识理解和掌握, 将理论知识和实 践教学紧密结合到一起, 促使中职学生能够得到更好的发展。我认为在 中职院校中, 教师可以积极探索现代化职业教育方法, 将中职院校当作 公司, 中职教师当作工厂中的师傅, 教室当作工厂的厂房, 而学生就看 成是学徒, 以这样的方式来开展中职教育, 可以有效培养学生的实践操 作能力并且所培养的学生能够符合社会对技术型人才的需要。另外, 为 了让学校和企业很好地结合, 中职院校可以构建一种旋转门机制, 也就 是学校与企业合作, 学校的教师与企业的技术工人定期部分互换, 这样 就可以更好地对学生的实践操作能力进行培养, 同时让他们对今后所要
从事的工作有更多的了解。

\section{3 坚持六个 “起来”}

和传统教育相同, 在我国现代化发展的过程中, 职业教育也发挥着 至关重要的作用, 随着科学技术水平的不断提升, 对职业教育提出了更 高的要求, 需要中职院校可以为社会提供更多的高技术水平的人才。所 以中职院校在对学校管理的过程中要坚持六个 “起来”: 香起来、亮起来、 强起来、忙起来、活起来和特起来, 一端瞄准产业, 一端瞄准学生, 为 我国经济升级铺路, 为我国实现脱贫攻坚助力。

第一、让职业教育香起来其实就是加强对职业教育的宣传力度, 让 人们意识到职业教育在我国经济发展的过程中所起到的重要作用, 为职 业教育发展提供思想前提。第二、让职业教育亮起来其实就是在对学生 开展教学的过程中时刻秉持质量意识, 将其贯穿于职业教学中, 提高中 职院校对学生的培养质量。第三、让职业教育忙起来其实就是要抓住经 济转型升级以及我国开展供给结构性改革这样一个机会, 主动对职业院 校的专业结构进行调整, 从而更好地满足社会对技术型人才的需要。第 四、让职业教育强起来其实就是将学校建设在开发区, 将中职院校中的 学科建设在产业链上, 下功夫培育职业教育发展后劲, 不为升格、不图 虚名, 实现职业院校在专业、管理、特色上的全面成长。第五、让职业 教育活起来其实就是贯彻好 《职业教育法》和《民办教育促进法》, 推进 放、管、服改革, 落实省级统筹权和职业院校办学自主权, 为职业教育 提供更大政策支持。第六、让职业教育特起来其实就是把职业教育打造 成 “名优土特产品”, 培养一批名师, 提供优质教学, 服务区域经济社会 发展, 实现专业、技能、教学方法各方面特色发展, 推进产学结合, 把 职业教育打造成闪光品牌。

\section{4 结束语}

综上所述, 随着时代的不断发展, 中职院校也应该及时更新和优化 管理理念, 中职教师应该树立正确的育人观念, 坚持以人为本的育人理 念, 同时还应该加强对中职学生的实践教学, 培养学生的实践动手操作 能力, 另外, 中职院校在办学的过程中要坚持六个 “起来”, 提升中职教 育的质量, 促使中职院校得到更好的发展。

\section{[参考文献]}

[1]金本能.李柱梁.新发展理念引领下职业教育的发展路径 [J].河南 科技学院学报.2018.38(6): $1-5$.

[2]薛文庆.浅谈职业中学的育人理念[J].成功 (教育), 2011(9):132.

[3]刘玉秀.论学校管理中的以人为本[J].教育教学论坛.2013(48)

[4]何永胜.学校管理要以人为本[J].湖北函授大学学报.2010(01) 